\title{
Research Paper Price movements of redgram major markets in India by using cointegration analysis
}

See end of the paper for authors' affiliations

Correspondence to :

R. Vijaya Kumari

Department of Agricultural

Economics (A.M.I.C.),

College of Agriculture,

Professor Jayashankar

Telangana State Agricultural

University, Hyderabad

(Telangana) India

Paper History :

Received : 05.06.2019;

Revised :08.07.2019;

Accepted : 09.08.2019
ABSTRACT : The main objective of the study is to assess cointegration of major redgram markets and price movement in major markets in India using important econometric tools like Augmented dickey-fuller (ADF), Johansen's cointegration test, granger causality test and vector error correction model (VECM). The results of the study indicated that in the long-run there was a two direction relationship between market prices. There is bidirectional causality affected on redgram prices redgram prices of Mumbai - Indore and Mumbai -Amravati. There is unidirectional causality affected on redgram prices of Amravati-Vijayawada, Gulbarga - Tandur, Gulbarga-Vijayawada, Indore -Vijayawada, Mumbai-Vijayawada. Results of vector error correction model (VECM) showed Mumbai market one month lag price is affecting current prices of Gulbarga market. Amravati market one month lag price is affecting current prices of Vijayawada market. Tandur market two months lag price is affecting current prices of Gulbarga and Amravati markets.

KEY WORDS : Price movements, Redgram major markets, Using cointegration analysis

How To Cite This PAPer : Kumari, R. Vijaya, Ramakrishna, Gundu, Venkatesh, Panasa and Sreenivas, Akula (2019). Price movements of redgram major markets in India by using cointegration analysis. Internat. Res. J. Agric. Eco. \& Stat., 10 (2) : 234-239, DOI : 10.15740/HAS/IRJAES/10.2/234-239. Copyright@ 2019: Hind Agri-Horticultural Society. 